\title{
Study on Growth Strategies of the Magazine Industry in the Digital Platform
}

\author{
Byeong-Hyun Min1), SiChul Kim²)
}

\begin{abstract}
This study aims to come up with a revenue model for the magazine industry in the digital environment and find the best practices in Korea and overseas. To find the best practices, this study diagnosed the reality of magazines, analyzed the current state and condition of the digital platform, conducted focus-group interviews with leading magazines, collected best practices of Korean and global magazines, developed and standardized a revenue model, generated a future vision, and analyzed support measures for policy implementation. The results of this study showed that, in order for magazines to survive and perform a desirable role in the rapidly changing media environment, they need specialized knowledge about the rapid changes of media, as well as the will and effort to aggressively fulfill the innovation. Furthermore, they must also actively implement systems to nurture managers or staff in the digital media era, to discover and develop best practices of digital and internet services, and to expand the awareness of success.

Keywords : magazine, expert, platform, U-Magazine
\end{abstract}

\section{Research background and objective}

This study aims to come up with a revenue model for the magazine industry in the digital environment and find the best practices in Korea and overseas. Three directions have been set for the research: 1) analysis of the concept, characteristics, and environment of magazines and magazine industry in the digital era; 2) in-depth interviews with leading Korean and global magazine groups; and 3) case studies of best practices in Korea and overseas to implement a revenue model. This study diagnosed the reality of magazines, analyzed the current state and condition of the digital platform, conducted focus-group interviews with leading magazines, collected best practices of Korean and global magazines, developed and standardized a revenue model, generated a future vision, and analyzed support measures for policy implementation. This study is differentiated in that it is not merely a survey or theory that has already been discovered; instead, it visited magazine publishing companies to investigate the current state and best practices of the digital platform regarding the subjects in [Table 1],

Received(October 16, 2017), Review Result(1st: November 8, 2017, 2nd: November 30, 2017), Accepted(December 10, 2017)

${ }^{1}$ Dept. Media Communication, ChungWoon Univ.,25,Daehak-gil, Hongseong-eup, Hongseong-gun, Chungnam, 32244, Korea email: cameramin@chungwoon.ac.kr

${ }^{2}$ (Corresponding Author)Dept. Media Communication, SungKyunKwan Univ., 25-2, SungKyunKwan-Ro, Jongno-Gu, Seoul, 03063, Korea email: helper@mjplex.co.kr

* This study was supported by research fund from ChungWoon University, 2015 
drew implications in the field, and came up with a model (Number of interviewees: 16 people in focus-group interviews).

[Table 1] Subjects of focus-group and expert interviews

\begin{tabular}{c|l|c|c}
\hline Division & \multicolumn{1}{|c|}{ Subject } & Interviewee & \multicolumn{1}{c}{ Remarks } \\
\hline Focus-group interview & $\begin{array}{l}\text { Magazine publishing } \\
\text { companiesand } \\
\text { magazineinstitutions }\end{array}$ & 16 people & 2 sessions \\
\hline \multicolumn{2}{c|}{ Total } & 16 people & 14 types \\
\hline
\end{tabular}

There have been many studies on the theoretical aspect of magazines and the publishing industry in Korea, but very few of them are related to industrial settings [1-14]. By not merely focusing on theories or overlooking the reality, policy research originating from the precise condition of industrial settings may help to set the Direction for policy implementation to better understand and lead the field. Therefore, there is a need for an empirical research that encourages people to enthusiastically agree with and participate in national media policies by creating a bond in industrial settings.

\section{Ecological environment of the magazine industry}

The first part of this study analyzes the concept, characteristics, and environment of the magazine industry. To this end, a general analysis of magazines in Korea was conducted, followed by an analysis on recent data (2016) of public institutions related to the magazine industry. For the recent data, the following was reorganized for maximum presence or sense of reality: environment of producing digital magazines and contents related to this topic; business analysis (revenues), distribution, and advertising environment; and status of global expansion. Documents reviewed, as of the end of 2016, included "Registration Status of Periodicals" (Jan. 2016); "2016 Business Performance" of corporate disclosure magazine publishing companies by the Ministry of Culture, Sports, and Tourism (Financial Supervisory Service electronic disclosure system, Apr. 2016); "2015 Audit Bureau of Circulation of Magazines" by the Korea Audit Bureau of Certification (May 2016); and "2013, 2015 Survey of the Magazine Industry" $(2014,2016)$ by Korea Press Foundation. This study also came up with the significance and implications of each individual analysis and applied them as significance of a diagnostic survey on practical cases later. A summary of the research findings in the ecological environment shows that, in analysis of the registration of periodicals, the ratio of free magazines is $35.5 \%$ of charged magazines and most of the magazines are published monthly or quarterly.

The business performance of corporate disclosure magazines in 2016 showed a year-on-year increase of 800 million KRW $(+2.3 \%)$ in sales (average), but a decrease of 280 million KRW $(-11.9 \%)$ in operating income 
(average) and a decrease of 400 million KRW (-20.6\%) in net income (average), showing de-growth. The number of copies published decreased by 22.5\%, from an average of 15,554 copies in 2014 to 12,055 copies in 2016, and the number of charged copies rapidly decreased by $34.0 \%$, from an average of 11,454 copies in 2014 to 8,418 copies in 2016 , showing a $14.8 \%$ decrease in the ratio of charged magazines, from $73.6 \%$ in 2014 to $62.7 \%$ in 2016 . In the survey of the magazine industry, $30.1 \%$ responded that they had plans for running a digital magazine with online publication, for reasons such as "adaptation to media changes" (49.1\%), "decrease of offline readers" (30.7\%), and "cost reduction" (20.1\%). The point of shifting to online media was "in 2015" (24.4\%), "2016-2018" (33.6\%), and "after 2018" (42.0\%), indicating that the shifting point is not up to date with the changes in the media environment. Services provided in the shift of publication were "purchase of external digital solutions and itself" (40.2\%), "introduction of digital portal or distribution app" (32.5\%), and "own magazine app development and itself" (25.1\%), indicating that most are dependent on outsourcing. The internet services currently provided are the magazines' own websites (34.2\%) and portal sites/online bookstores(15.8\%), but those that will be provided in the future are showing an increase in tablet PCs (36.5\%), smartphones (34.2\%), electronic magazine websites (32.9\%), and portal sites/online bookstores $(15.5 \%)$, but a decrease in own websites $(5.1 \%)$. The result of business analysis shows that the net income for 2016 was in the average of 390 million KRW, and $64.1 \%$ of magazine publishing companies have a net income of less than 100 million KRW, which shows the modest scale of magazine publishing companies. In terms of distribution and advertising environment, the most common distribution channel was "subscription" (43.2\%), followed by "sole distributors" (15.4\%), and "bookstores" (7.0\%). Meanwhile, regarding difficulty in magazine sales, $25.8 \%$ responded that it is "generally difficult" in the sales distribution network. For advertising sales, $32.8 \%$ responded that it is "generally difficult" in the lack of advertising experts (32.8\%), lack of awareness of advertisers (29.8\%), and development of a new advertising market (25.2\%). For other specific matters, $71.1 \%$ responded "none" for the ratio of advertising revenue from the government, local governments, and public institutions, which takes up an absolute majority. With regard to the overseas export of magazines, $7.5 \%$ responded "yes" and 91.8\% responded "no," whereas for overseas export of magazine contents, $1.2 \%$ responded "yes," 69.0\% responded "no," and 29.8\% responded "don't know." For licensing overseas, 2.5\% responded "yes" and 96.8\% responded "no," which proves the lack of overseas expansion of Korean magazines.

\section{Analysis of focus-group interviews}

Focus-group interviews were conducted with magazine publishers and institutions. A total of 16 participants were interviewed, 14 publishers and 2 employees of magazine institutions, conducted in two sessions. The interviewees were adequately formed by field of publication and content, according to the classification system of the Korea Magazine Association. Questions are mainly related the topic of this study, such as digital content 
production environment, improvement plans regarding operation of U-Magazine, business environment and revenue generation, distribution and advertising status, overseas market expansion plans, and policy support measures.

A summary of key research findings about focus-group interviews showed that there were many positive opinions that generating profits online in a content production environment (digital platform) requires too much cost to self-manage and thus it is more beneficial to cooperate with the association, and that there were also many advisory opinions pointing out current operational issues. Furthermore, some opinions were about sending emails to clients or advertisers regarding online articles or providing newsletters on SNS, having video-filming reporters film the seminars and providing them for free. As for business environment (revenue generation), there were views about how the magazine quality has deteriorated and sales revenues have reduced by increased deficits when the economic recession in Korea hit the magazine advertising the hardest. Thus, it is necessary for magazines to face this reality, of how they are growing further away from their readers, to figure out whether they can secure excellent human resources and reporters for good features and coverage, and to create content that readers would actually pay for to read or watch online. The interviewees also emphasized the need to develop a revenue model through business incidental to magazines, such as marketing or promotion, in order to sell more magazines. Moreover, they emphasized the need to establish measures against the discrimination of existing newspapers about coverage of magazine articles and insufficient provision of press releases, to provide magazine articles to post on portals such as Naver, and to review methods of charging for the service. With regards to the advertising and distribution status, they talked about a lack of perception on magazine advertising and overcoming the alienation of magazine advertisements, the need for policy support according to a marked decline of advertising due to the relocation of the government or large corporations to provinces, an improvement of the $\mathrm{ABC}$ system related to government advertising to fit the magazines, the implementation of a distribution support method of Korea Press Foundation to support poor distribution status, and a shift to the subscription system by using a membership scheme focusing on loyal readers.

For methods of overseas market expansion, the interviewees talked about increasing business funds and extending periods by activating the translation project of the association. In addition, in terms of market development, it would be better to export magazines in cooperation with the association and have agencies become in charge of collecting money. Then, when there is a problem, the association shall make a line to solve the problem.

When entering China, it would be better to form a consortium with other companies rather than entering in solo. As for policy support measures, they said that it is necessary to promote national awareness of reading by having public libraries, schools, public institutions, and general companies purchase the magazines, which also raises the need to establish a system to allocate advertisements uniformly to struggling magazines as part of a policy. They also requested the increased selection of magazines with excellent content, increased supply 
of magazines to public and national libraries, and expanded scope of relevant divisions for reading campaigns in the government to include magazines as well.

\section{Analysis of revenue models}

For revenue generation in the digital platform, this study categorized the production type of digital magazines into PDF and interactive types, which are set as one standard according to the method of providing and using the articles. As a platform to organize and present information, the revenue models were examined in four types, such as individual PDF, comprehensive PDF, app interactive, and web interactive.

[Table 2] Comparison of revenue models in the digital magazine industry

\begin{tabular}{|c|c|c|c|c|}
\hline Division & Individual PDF & Comprehensive PDF & App interactive & Web interactive \\
\hline $\begin{array}{l}\text { Providing } \\
\text { information }\end{array}$ & $\begin{array}{l}\text { Shift from printed } \\
\text { to digital magazines }\end{array}$ & $\begin{array}{l}\text { Integrated presentation } \\
\text { of various magazine } \\
\text { files }\end{array}$ & $\begin{array}{l}\text { Suitable for mobile } \\
\text { and tablet media }\end{array}$ & $\begin{array}{l}\text { Use of various } \\
\text { expression techniques } \\
\text { online }\end{array}$ \\
\hline Case & Simple PDF files & $\begin{array}{l}\text { Moazine } \\
(\text { moazine.com) }\end{array}$ & U-Magazine & $\begin{array}{l}\text { Online portals, } \\
\text { K-Magazine }\end{array}$ \\
\hline $\begin{array}{l}\text { C o s t } \\
\text { structure }\end{array}$ & $\begin{array}{l}\text { Minimized human } \\
\text { resources, equipment, } \\
\text { and time }\end{array}$ & $\begin{array}{l}\text { Need human resources } \\
\text { to manage integrated } \\
\text { website }\end{array}$ & $\begin{array}{l}\text { Need human } \\
\text { resources to process } \\
\text { and redesign app and } \\
\text { digital contents }\end{array}$ & \begin{tabular}{ll}
\multicolumn{3}{l}{ Need human resources } \\
to process and \\
redesign app and \\
digital contents
\end{tabular} \\
\hline $\begin{array}{l}\text { Re v e n u e } \\
\text { structure }\end{array}$ & $\begin{array}{l}\text { Limited additional } \\
\text { margin }\end{array}$ & $\begin{array}{l}\text { Partial increase of } \\
\text { additional margin }\end{array}$ & $\begin{array}{l}\begin{array}{l}\text { Generation of } \\
\text { revenues } \\
\text { advertising, } \\
\text { business, and sales }\end{array} \\
\end{array}$ & $\begin{array}{l}\text { Generation } \\
\text { revenues } \\
\text { advertising, } \\
\text { business, and sales }\end{array}$ \\
\hline $\begin{array}{l}\text { Characterist } \\
\text { ic }\end{array}$ & $\begin{array}{l}\text { Low cost, low } \\
\text { income }\end{array}$ & $\begin{array}{l}\text { Low cost, middle } \\
\text { income }\end{array}$ & $\begin{array}{l}\text { Middle cost, middle } \\
\text { income }\end{array}$ & $\begin{array}{l}\text { Middle cost, middle } \\
\text { income }\end{array}$ \\
\hline
\end{tabular}

This study compares and reviews the four revenue models currently operated by the digital industry, combines the advantages, and proposes a "complex revenue model" as a new model for the reality in Korea. This model is a system that forms a portal site for major magazines and small- or mid-sized magazines to participate together, and it enables magazine buyers to select, purchase, and consume a certain number of magazines as needed, which is similar to how cable TV and IPTV stations provide channels.

[Table 3] Complex revenue generation method of digital magazines

\begin{tabular}{c|l|c|c}
\hline Division & \multicolumn{3}{|c}{ Main content of model } \\
\hline \multirow{3}{*}{ Characteristics } & $\begin{array}{l}\text {-Mixed use of methods to provide magazine content used by the four existing models } \\
\text {-Needs government support and investment, and anticipates growth of the overall digital } \\
\text { magazine industry }\end{array}$ \\
\hline Division & \multicolumn{1}{|c|}{ Basic type } & Specialized type & Premium type \\
\hline
\end{tabular}




\begin{tabular}{|c|c|c|c|}
\hline Type & $\begin{array}{l}\text {-Free service of basic } \\
\text { information selected by the } \\
\text { magazine association }\end{array}$ & $\begin{array}{l}\text {-Charged use of bundles or } \\
\text { individual magazines in } \\
\text { each field of specialization }\end{array}$ & $\begin{array}{l}\text {-Charged use of } \\
\text { publications by major } \\
\text { magazine publishing } \\
\text { companies individually or } \\
\text { by company }\end{array}$ \\
\hline Division & Human resources & Equipment, technology & Time required \\
\hline Cost & $\begin{array}{l}\text {-Need human resources for } \\
\text { site operation, web content } \\
\text { development and design }\end{array}$ & $\begin{array}{l}\text {-Need investment for app } \\
\text { and web development and } \\
\text { operation }\end{array}$ & $\begin{array}{l}\text {-Around three days, } \\
\text { depending on the amount } \\
\text { of content }\end{array}$ \\
\hline Division & Advertising & Business (event) & Content sales \\
\hline Income & $\begin{array}{l}\text {-Can adopt various methods } \\
\text { such as native advertising, } \\
\text { etc. }\end{array}$ & $\begin{array}{l}\text {-Can promote specific } \\
\text { businesses }\end{array}$ & -Expected to increase \\
\hline
\end{tabular}

The advantage of the new "complex revenue model" is that it accepts various types of digital contents, considering the constantly changing digital environment. As the government's support policy for excellent magazines, this is anticipated to increase public interest of content, to promote content competitiveness of specialized magazines, and to create an environment for coexistence of premium magazines and small- or mid-sized magazines. Some examples of government support measures for magazine publishing companies, which are enthusiastic about this model, are as follows: increased selection and supply of magazines with excellent content, support for features and coverage as well as business consulting, discovery of Korean wave magazines and translation, support for development and expansion of potential readers, and magazine sponsorship and support for the underprivileged.

\section{Conclusion}

The analysis results of the interviews with people in the magazine industry shows that there are many difficulties in the environment to create digital content, such as the method for providing digital services, opinions about revenue generation, creation of good content, development of overseas markets, and future visions and policies of digital magazines. Most interviewees were setting a high value on the need to publish magazines through the digital platform; they emphasized the balance of online and offline production structure, as well as online news services, and presented opinions about the real difficulty of finding and nurturing competent human resources to develop contents. Regarding business environment and revenue generation, this study analyzed the trend income and expenditure in management as well as business condition in terms of overall income. Most interviewees expressed negative opinions about the management trend, pointing out the economic recession in Korea and poor advertising sales, reduction of the magazine market by new media, difficulty in distribution, and excessive competition with existing media. As for distribution and advertising status, they talked about the decrease of the advertising market and difficulty in advertising; difficulty in 
obtaining orders for advertising from the government, local governments, or public institutions; opinions and about the $\mathrm{ABC}$ system or relationships with agencies. Regarding distribution, the interviewees provided measures against the current situation with issues about free or charged services, and distribution channels such as sole distribution, bookstores, and subscription. In terms of overseas market expansion, they were asked about the overseas export of magazines and content, as well as local and global licensing. Some interviewees mentioned that they have already entered China, and talked about related issues and other partial affiliation and translation costs. As a result of comprehensively analyzing the current situation, it can be seen that the mission to develop into a digital magazine industry requires actual efforts for self-innovation and development by the magazine industry, along with national policy support. The magazine industry must reinforce the power to survive and compete, and magazines must make efforts to overcome the difficulties in the digital magazine industry by efficiently producing and publishing digital magazines, implementing good marketing and distribution, and coming up with a business model and generating revenues. In other words, there is a need for methods to resolve pending issues and holistic measures for development and growth, such as the magazine industry's effort and the government's support, so that magazines can become a part of a future-oriented industry. Regarding policy support the government must support magazines to become a part of a future-oriented industry and grow into a digital industry by efficiently producing and publishing digital magazines, implementing good marketing and distribution, coming up with a business model, and generating revenues.

In conclusion, as a suggestion for future development, it is necessary to promote the competitiveness of magazines such as the challenges of "magazine people" in the era of digital magazines, an understanding of the digital magazine era and a will for its implementation, and self-effort and response. 


\section{References}

[1] Axel Sprigner SE (2015). Geschaeftsbericht 2014. Berlin.

[2] FIPP(2011). Innovations in Magazines 2011 World Report

[3] Gruner Jahr (2015). Geschaeftsbericht 2014. Hamburg.

[4] Hubert Burda Media (2015). Konzernabschluss 2014. Offenburg.

[5] Kommission zur Ermittlung der Konzentration im Medienbereich (KEK) (2015).

[6] Meier, Christian (2008). Einer für alle, alle für einen. Der Tagesspiegel 2008.12.16.

[7] Scoop (2014). Einer für alle, alle für einen. Scoop (http://www.scoop.co.nz/stories/BU1401/S00345/metro-publisher-bauer-cleared-to-buy-apn-magazines.htm).

[8] Vogel, Andreas (2014). Publikumszeitschriften 2014. Medie Perspektiven 2014(6), pp.347-371.

[9] http://dart.fss.or.kr (2016)

[10] http://www.mcst.go.kr (2016)

[11] http://www.kpf.or.kr (2016)

[12] http://www.magazinei.org (2016)

[13] http://www.magazine.or.kr (2016)

[14] http://www.kocca.kr (2016) 